\title{
Design and Implementation of an Efficient Bio-Implantable Planar Spiral Stacked Coil
}

\author{
Saad Mutashar and Ahmed S. Ezzulddin \\ Department of Electrical Engineering, University of Technology, Baghdad, Iraq \\ saad_ra25@yahoo.com
}

\begin{abstract}
This study deals with the design of an efficient small-sized bio-implantable planar spiral square stacked coils (double layer) based on inductive coupling links technique. The parasitic capacitances of the proposed design is insignificant, hence, the tuning capacitor of the equivalent circuit can be negligible. The external coil placed outside the human body with outer dimensions $\mathrm{d}_{\text {out }}=30 \mathrm{~mm}$ and inner dimension $\mathrm{d}_{\mathrm{in}}=7.6 \mathrm{~mm}$ with 15 number of turns. The internal double layer is designed to be inserted within human tissue and having outer dimensions $\mathrm{d}_{\text {out }}=10 \mathrm{~mm}$ and inner dimension $\mathrm{d}_{\mathrm{in}}=7.6 \mathrm{~mm}$ with 3 number of turns for each layer. The High Frequency Structural Simulator (HFSS 14.1) is used to design and simulate the coils in the air and within the phantom human tissue. Mathematical formulas, simulation and experimental results are introduced to validate the proposed design. The results show that the stacked coils with double layer have better efficiency than single layer by $2.7 \%$ on air and $9.71 \%$ within the phantom tissue. The results also, validated by compression with other previous researcher. To prove that the proposed double layer coil cannot damage the human tissue the SEMCAD 16.4 Software is used. The proposed design is suitable for implantable medical devices such as a nerves stimulators.
\end{abstract}

Key words: Implantable medical devices, ISM band, inductive coupling link, planar spiral coils, HFSS Software, insignificant

\section{INTRODUCTION}

Wireless Power Transfer (WPT) is the transmission of electrical energy from the power source to an electrical load without the use of wires. WPT is suitable in cases where using wires are hazardous, difficult or non-existent. WPT using inductive coupling links is becoming widely used for charging of portable electronics devices and biomedical implants, electric vehicles, etc. (Hannan et al., 2014). An optimal pair of square Printed Spiral Coils (PSCs) for general implantable microelectronic devices based on theoretical semi-empirical models is designed (Jow and Ghovanloo, 2007). The power transmission efficiencies of this design are 41.2 and $85.8 \%$ at 1 and 5 $\mathrm{MHz}$ operating frequencies, respectively. The size of the receiver coil is $20 \times 20 \mathrm{~mm}^{2}$. Thus, the size is the issue which is maybe not practical for most implantable microelectronic devices.

Three examples of Pairs Square (PSCs) for Neuroprosthetic implantable devices at 5,10 and 13.56 $\mathrm{MHz}$ with coupling distance $10 \mathrm{~mm}$ for $10 \times 10 \mathrm{~mm}^{2}$ implanted outer diameter coil are optimized. The efficiencies obtained were 42.1, 52 and $56.65 \%$, respectively. Typically, these efficiencies are low after taking the losses of the source, load and tissue in consideration (Jow and Ghovanloo, 2008). Again in 2009 , three design examples for an implantable device at $10 \mathrm{~mm}$ coupling distance, operating at $13.56 \mathrm{MHz}$ and $10 \times 10 \mathrm{~mm}^{2}$ receiver size are introduced (Jow and Ghovanloo, 2009). The Power Transmission Efficiencies (PTE) are 72.2, 51.8 and $30.8 \%$ in air, saline and muscles, respectively. The PTE is the issue in this design. In 2009 a proposed implantable microsystem is presented. The implanted chip is inductively powered by an rectangular external coil with a $13.56 \mathrm{MHz}$ carrier with $44 \mathrm{~mm}$ of dimensions and the rectangular internal coil with $4 \times 8 \mathrm{~mm}$. the coupling link efficiency of this design is relative small (Ahmadi and Jullien, 2009).

The pair PSCs operated at $13.56 \mathrm{MHz}$ is presented to achieve $71.1 \%$ of efficiency at $10 \mathrm{~mm}$ relative distance to power $10 \times 10 \mathrm{~mm}^{2}$ implanted coil (Wu and Fang, 2011). The results show that the peak power transmission efficiency in human biological tissues is $15.2 \%$ and the frequency corresponding to the peak power efficiency shifted to $8 \mathrm{MHz}$. The double layers PSCs for medical wireless power transmission in implantable were designed with $79.8 \%$ of power transmission efficiency at $5 \mathrm{MHz}$. The size of the receiver is $11 \times 11 \mathrm{~mm}$ (Ashoori et al., 2011). This technique is capable of increasing the quality factors of the coils and the coupling c oefficient of the coils pair for

Corresponding Author: Saad Mutashar, Department of Electrical Engineering, University of Technology, Baghdad, Iraq saad_ra25@yahoo.com 


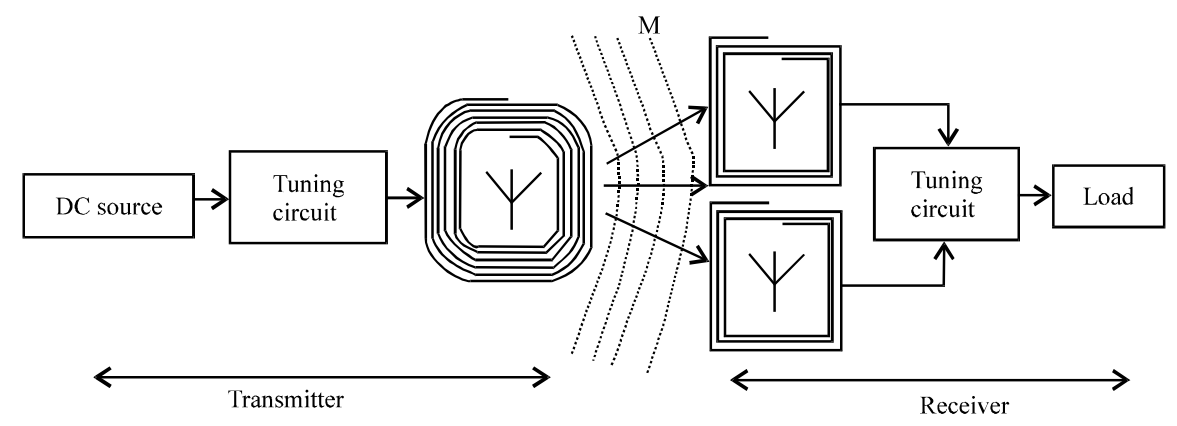

Fig. 1: The proposed block diagram with stacked coil

a given size. Rectangular coils with $62 \times 25 \mathrm{~mm}^{2}$ external coil and $25 \times 10 \mathrm{~mm}^{2}$ internal coil for a nominal distance of $10 \mathrm{~mm}$ between coils at $13.56 \mathrm{MHz}$ is designed to achieve an efficiency of 69\% (Andia et al., 2011). In 2014 the reflected impedance method of the inductive coupling link using circular coils was used to design implantable microsystems simulator with $80 \%$ of efficiency (Mutashar and Hannan, 2013). This system was designed at $13.56 \mathrm{MHz}$ in the air and within the two types of tissue (dry and wet skin). The outer external coil dimension is 56 $\mathrm{mm}$ and the outer implanted coil dimension is $11.6 \mathrm{~mm}$ where the size of the transmitter coil is relatively large.

A pair of PSC for wireless powering brain implantable sensor is designed with transmitter and receiver coils having diameter 30 and $10 \mathrm{~mm}$, respectively, at $13.56 \mathrm{MHz}$. The achieved efficiency are 80 and $20 \%$ for 5 and $20 \mathrm{~mm}$ distances, respectively (Stocklin et al., 2015). Four coils WPT system with small implanted square coil $5 \times 5 \mathrm{~mm}$ were suggested to be compared with two and three coils systems (Yang et al., 2017). The transmission efficiencies of this design at $10 \mathrm{~mm}$ transmission distance is relatively small.

In this research, an efficient small-sized bioimplantable planar spiral square stacked coils (double layer) based on inductive coupling links technique at 13.56 $\mathrm{MHz}$ is proposed. The square planar spiral transmitter coil is used to transmit power to the small size implantable staked coil inductively. Simulation and experimental measurement results are introduced to validate the proposed design. The results show that the stacked coils with double layer have better efficiency than single layer by $2.7 \%$ on air and $9.71 \%$ within the human phantom tissue. In addition, the proposed double layer coil cannot damage the human tissue.

Model design approach: The block diagram of the proposed design with a single layer transmitter and double layer square-shaped PSC receiver is presented in Fig. 1. To validate the advantage of the double layer over the single layer, a receiver with a single layer with an approximately same size will also be designed for comparison. The double layer receiver with small size provides a significantly higher inductance, higher quality factor and higher coupling coefficient. Also, allows increasing the conductor width which reduces the series resistance which in turn increases the quality factor of the PSC in addition, more optimal inner diameter can be chosen.

Proposed transmitter and receiver with single layer design: In this study, the first proposed design of the transmitter and the single layer receiver is design using HFFS 14.1 which will be compared with the proposed double layer design. The biomedical applications place a lower limit on the distance between the transmitter and receiver coils $\left(\mathrm{d}_{\mathrm{r}}\right)$ and an upper limit on the size of the coil receiver $\left(\mathrm{d}_{\text {out } 2}\right)$ which is typically implanted in the body (Hannan et al., 2014). The relationship between the transmitter and receiver is considered based on the methods by Mutashar and Hannan (2013). The calculated parameters and geometric dimensions of the both proposed coils is given in Table 1. The medium between coils is air and the coupling distance between the PSCs is considered $6 \mathrm{~mm}$ which agree with the implantable micro-system stimulators (Mutashar and Hannan, 2013). All proposed coils in this study printed on substrate thickness $1 \mathrm{~mm}$ and dielectric constant $\varepsilon r=4$. 4 . Figure 2 shows the geometrical parameters and the eqivalent circuit of PSC. Figure 3 shows the transmitter and the aligned single layer receiver on air.

Proposed stacked coils (double layer) receiver design: To increase the inductive coupling, the quality factor and inductance should be high. Stacked coils allow to achieving a high inductance, high-quality factor coils with smaller or same size of the single coil (Bahl, 2003). For a two-layer stacked coil (double layer) shown in Fig. 4, the total inductance can be written as:

$$
\mathrm{L}_{\mathrm{d}}=\mathrm{L}_{\mathrm{s} 1}+\mathrm{L}_{\mathrm{s} 2} \pm 2 \mathrm{M}_{\mathrm{s}}
$$


Fig. 2: a) Geometrical parameters of the single layer square PSC; b) The eqivalent circuit of PSC and c) The eqivalent circuit with tuning Capacitor $\mathrm{C}_{\mathrm{r}}$
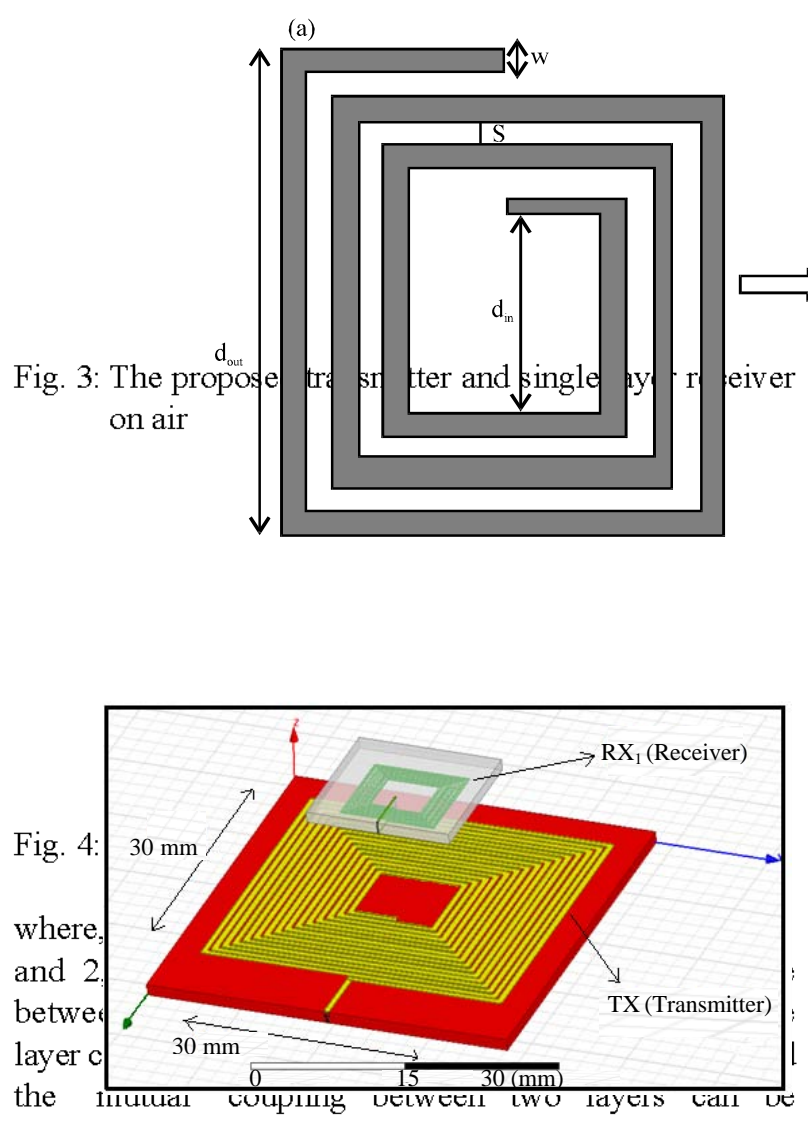

given as:

$$
\mathrm{M}_{\mathrm{s}}=\mathrm{k}_{\mathrm{s}} \sqrt{\mathrm{L}_{\mathrm{s} 1} \mathrm{~L}_{\mathrm{s} 2}}=\mathrm{k}_{\mathrm{s}} \mathrm{L}_{\mathrm{s}}
$$

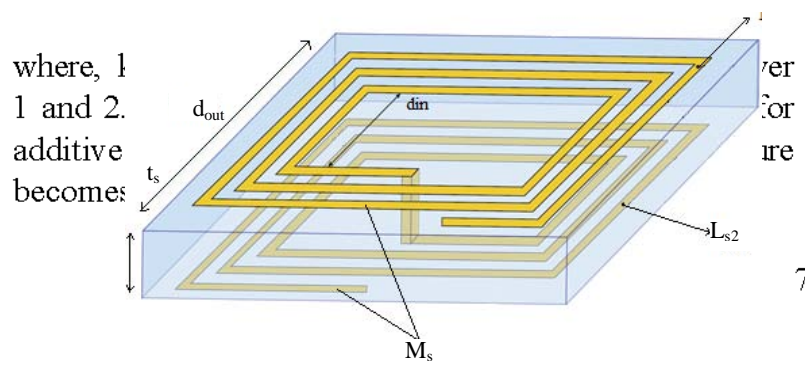

W(b)ere:

$$
\text { th }
$$

the nutual cospling $\mathrm{Ms}$ shquld be estimate first in order to collculate $\mathbb{R}_{\mathrm{p}}$. The parasit $\mathcal{C}_{\mathrm{p}}$ Capaq tance $\mathrm{Cp}-1$ ) of the

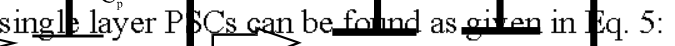

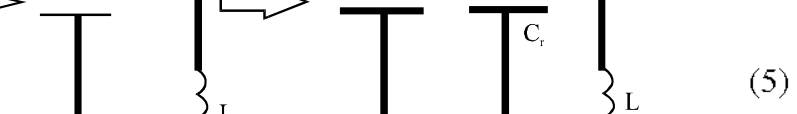

where, SRF presents the se f-resonat frequencies of the PSC And because of single layer transmitter is $\mathrm{SRF}<5 \mathrm{f}$ where, $\mathrm{f}=13.56 \mathrm{MHz}$, then the parasitic capacitance should be carefully calculated (Medhurst, 1947). The parasitic capacitor can be estimated after dividing $\mathrm{C}_{\mathrm{P}}$ into $\mathrm{C}_{\mathrm{PC}_{\mathrm{d}}}$ and $\mathrm{C}_{\mathrm{PC}}$ (Jow and Ghovanloo,
2009):

$$
\mathrm{k}_{\mathrm{s}}=\mathrm{M}_{\mathrm{s}} / \mathrm{L}_{\mathrm{s}}
$$

An additional parasitic capacitance is created between the conductor lines in the upper and lower layers of the double layers PSCs with the substrate as a dielectric as it is illustrated in Fig. 5. This parasitic capacitance can be estimated as giten in Eq. 7:

$$
\begin{aligned}
& C_{p-L}=\frac{\varepsilon_{\mathrm{Fr} 4} \varepsilon_{0} 1_{\mathrm{c}} \mathrm{W}}{\mathrm{t}_{\mathrm{s}}}
\end{aligned}
$$

Where:

$1_{c}=$ The conductive length in each layer

$\mathrm{t}_{\mathrm{s}}=$ The thickness of the FR4 substrate

$$
\mathrm{C}_{\mathrm{p}}=\mathrm{C}_{\mathrm{pc}}+\mathrm{C}_{\mathrm{ps}}=\frac{\left(\alpha \epsilon_{\mathrm{r}}+\beta \in_{\mathrm{FR} 4}\right) \in_{0} \mathrm{t}_{\mathrm{s}} 1_{\mathrm{g}}}{\mathrm{s}}
$$




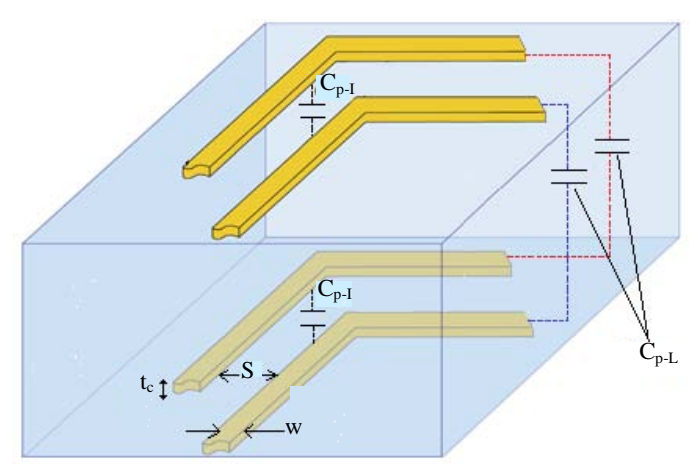

Fig. 5: Parasitic capacitances of a double layer PSC

Hence, the overall parasitic capacitance of double layer PSCs is found from:

$$
\mathrm{C}_{\mathrm{p}}=\frac{\mathrm{C}_{\mathrm{p}-1}}{2}+\mathrm{C}_{\mathrm{p}-\mathrm{L}}
$$

This signifies that using double layer PSCs produces a higher parasitic capacitance and decreases the SRF of the PSCs.

Since, the conductor length of the double PSC layer is twice the length of the single PSC layer, the series parasitic resistance can be easily calculated by:

$$
\mathrm{R}_{\mathrm{s}}=2 \mathrm{R}_{\mathrm{dc}} \frac{\mathrm{t}_{\mathrm{c}}}{\delta\left(1-\mathrm{e}^{-\mathrm{t}_{\mathrm{c}} / \delta}\right)}
$$

To find the mutual inductance $(\mathrm{M})$ between the single transmitter and double layer receiver Eq. 10 and 11 are used (Raju et al., 2014):

$$
M=\rho \times \sum_{i=1}^{1=n 1} \sum_{j=1}^{j=n 2} M_{i j}
$$

Where:

$$
M_{i j}=\frac{\mu_{0} \pi a_{j}^{2} b_{1}^{2}}{2\left(a_{i}^{2}+b_{j}^{2}+D^{2}\right)^{3 / 2}}\left(1+\frac{15}{32} \gamma_{i j}^{2}+\frac{315}{1024} \gamma_{i j}^{4}\right)
$$

Where:

And:

$$
\begin{aligned}
& \mathrm{a}_{\mathrm{i}}=\mathrm{r}_{1}-\left(\mathrm{n}_{\mathrm{i}}-1\right)\left(\mathrm{w}_{1}+\mathrm{s}_{1}\right)-\mathrm{w}_{1 / 2} \\
& \mathrm{~b}_{\mathrm{i}}=\mathrm{r}_{2}-\left(\mathrm{n}_{\mathrm{j}}-1\right)\left(\mathrm{w}_{2}-\mathrm{s}_{2}\right)-\mathrm{w}_{2 / 2}
\end{aligned}
$$

$$
\mathrm{y}_{\mathrm{ij}}=2 \mathrm{a}_{\mathrm{i}} \mathrm{b}_{\mathrm{j}} /\left(\mathrm{a}_{\mathrm{i}}^{2}+\mathrm{b}_{\mathrm{j}}^{2}+\mathrm{d}_{\mathrm{r}}^{2}\right)
$$

where, $\mathrm{dr}$ is a distance between coils and parameter (p) depends on the shape of the planar coils and calculate as given in Eq. 12 which is approximately equal 1 (Raju et al., 2014):

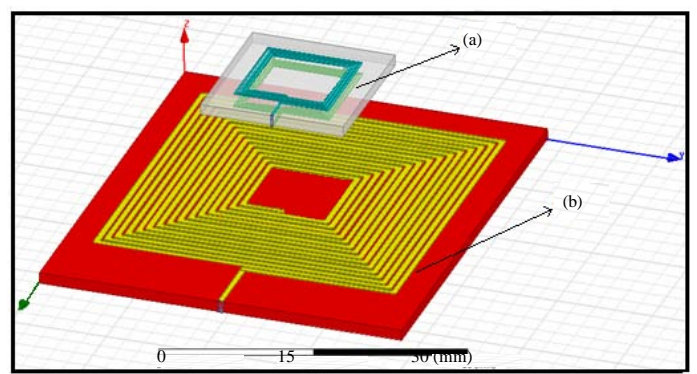

Fig. 6: 3D PSCs Model for: a) transmitter coil and b) implanted stacked coils (double layer) on air

Table 1: Geometries and parameters of the proposed Transmitter (TX), Single Receiver $\left(\mathrm{RX}_{1}\right)$ and double layer coils $\left(\mathrm{RX}_{2}\right)$

\begin{tabular}{llll}
\hline & & $\begin{array}{c}\mathrm{RX}_{1} \text {-single } \\
\text { layer }\end{array}$ & $\begin{array}{c}\mathrm{RX}_{2} \text {-double } \\
\text { layer }\end{array}$ \\
\hline Carameters & $\mathrm{TX}$ & 10 & 10 \\
Coil outer dimensions $\left(\mathrm{d}_{\text {out }}\right)(\mathrm{mm})$ & 30 & 10 & 7.6 \\
number dimensions $\left.d_{\text {in }}\right)(\mathrm{mm})$ & 7.6 & 5.5 & 3 each layer \\
Conductors width $(\mathrm{w})(\mathrm{mm})$ & 15 & 7 & 0.25 \\
Spacing between turns $(\mathrm{s})(\mathrm{mm})$ & 0.55 & 0.18 & 0.15 \\
Conductors thickness $\left(\mathrm{t}_{\mathrm{c}}\right)(\mathrm{mm})$ & 0.25 & 0.15 & 0.07 \\
inductance $\mathrm{L}(\mathrm{uH})$ & 0.07 & 0.07 & 0.789 \\
Series resistance $\mathrm{R}_{\mathrm{s}}(\Omega)$ & 5.05 & 0.676 & 1.026 \\
Parallel capacitance $\mathrm{C}_{\mathrm{p}}(\mathrm{pF})$ & 3.07 & 1.12 & 1.7 \\
SRF $(\mathrm{MHz})$ & 2.27 & 1.05 & 136 \\
\hline
\end{tabular}

$$
\rho=(4 / \pi)^{\mathrm{T}} \text { and } \tau=1+\mathrm{r}_{\min } / \mathrm{r}_{\max }
$$

For more accurate, the second layer of the stacked PSC has a distance with transmitter farther than the first layer by the thickness of the substrate (ts), therefore, the final expression will be:

$$
\begin{aligned}
& \mathrm{M}_{\mathrm{ij}}=\frac{\mu_{0} \pi \mathrm{a}_{\mathrm{i}}^{2} \mathrm{~b}_{\mathrm{j}}^{2}}{2\left(\mathrm{a}_{\mathrm{i}}^{2}+\mathrm{b}_{\mathrm{j}}^{2}+\mathrm{d}_{\mathrm{r}}^{2}\right)^{3 / 2}}\left(1+\frac{15}{32} \gamma_{\mathrm{ij}}^{2}+\frac{315}{1024} \gamma_{\mathrm{ij}}^{4}\right)+ \\
& \frac{\mu_{0} \pi \mathrm{a}_{\mathrm{i}}^{2} \mathrm{~b}_{\mathrm{j}}^{2}}{2\left(\mathrm{a}_{\mathrm{i}}^{2}+\mathrm{b}_{\mathrm{j}}^{2}+\left(\mathrm{d}_{\mathrm{r}}+\mathrm{t}_{\mathrm{s}}\right)^{2}\right)^{3 / 2}}\left(1+\frac{15}{32} \mathrm{y}_{\mathrm{ij}}^{2}+\frac{315}{1024} \gamma_{\mathrm{ij}}^{4}\right)
\end{aligned}
$$

Where:

$$
\gamma_{i j}=2 a_{i} b_{j} /\left(a_{i}^{2}+b_{j}^{2}+\left(d_{r}+t_{s}\right)^{2}\right)
$$

Moreover, the second proposed design of the transmitter and the stacked coils (double layer) receiver is design using HFFS 14.1. The calculated parameters and geometric dimensions of the proposed stacked coil is given in Table 1 also. Figure 6 shows the aligned single layers transmitter and the double layer receiver where the medium is the air. 


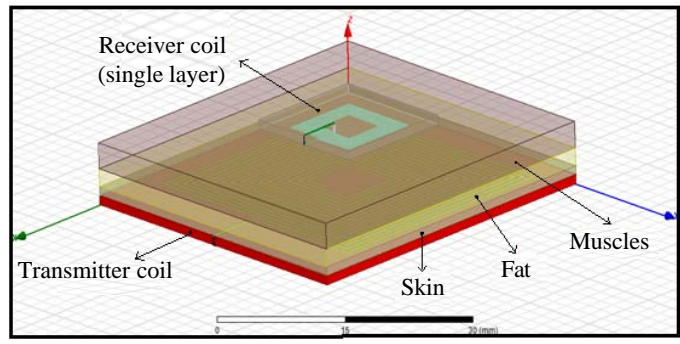

Fig. 7: 3D PSCs Model with human biological tissue for the transmitter with single layer receiver

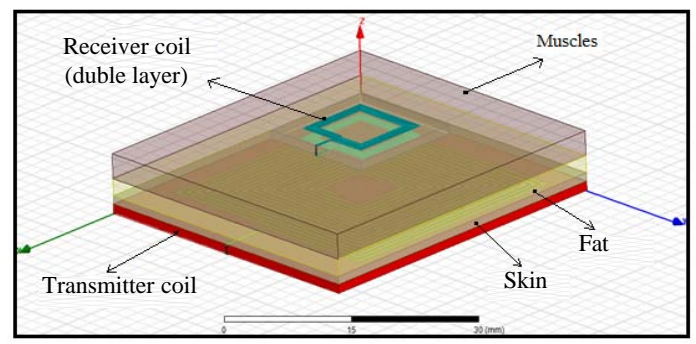

Fig. 8: 3D PSCs Model with human biological tissue for the transmitter with double layer receiver

Coils design within human tissues: To test the performance of the proposed design, both design in sections 2.1 and 2.2 tested within human tissue and as follow procedures.

The transmitter coil is placed outside the body and touch the skin whereas the receiver coil is considered as an implantable coil and planted inside the tissue at $6 \mathrm{~mm}$ of depth as seen in Fig. 7.

The transmitter coil placed outside the body and touches the skin whereas the receiver coil with the double layers is considered as an implantable coil and implanted inside the human tissue at $6 \mathrm{~mm}$ of depth as given in Fig. 8.

This $6 \mathrm{~mm}$ of depth is chosen by considering the tissue power absorption and it presents the distance between the coils. The simulated tissue consists of $1 \mathrm{~mm}$ skin and $2 \mathrm{~mm}$ fat followed by $3 \mathrm{~mm}$ muscles with dielectric properties at $13.56 \mathrm{MHz}$ to avoided the tissue damage (Mutashar and Hannan, 2013). To prove that, the proposed implanted double layer receiver cannot damage the human tissue, thus, the implanted double coil inserted on depth of $1 \mathrm{~cm}$ at the top of the head to combatable the deep brain stimulator using SEMCAD 16.4 Software (Mutashar and Hannan, 2013). The results show that the delivered power to the field implanted coil is lower than the standard level (Anonymous, 1993) where Delivered power $=$ Conductivity losses + Radiated power. (a)

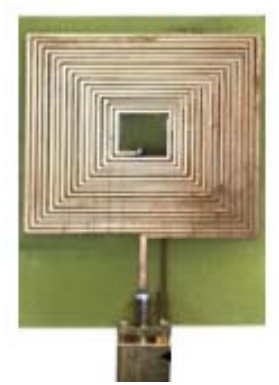

(b)

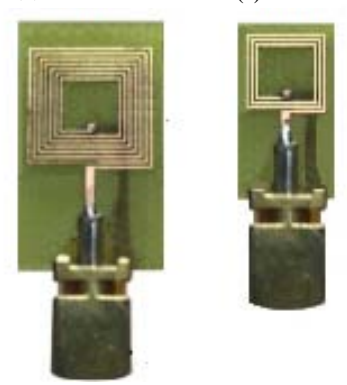

Fig. 9: Fabricated design of: a) Transmitter coil; b) Single layer receiver and c) double layer receiver

Coils fabrication and testing: The transmitter, single layer receiver and double layer receiver have been designed using ADS 2014 Software. Then these designs were converted to Gerber file which agrees with printer machine software. The proposed PSCs have been fabricated using 1-0Z copper wire ( $30 \mathrm{AWG}$ ) with $0.07 \mathrm{~mm}$ thickness and Rogers $4350^{\mathrm{TM}}$ substrate with thickness $\mathrm{t}_{\mathrm{s}}=1 \mathrm{~mm}$ and relative permittivity $\varepsilon_{\mathrm{r}}=4.4$ and printed on all proposed coils as shown in Fig. 9. The real and imaginary part of the PSCs for the transmitter and double layer receiver coil is also plotted and measured. To validate the proposed design, the measurements of the fabricate coils will be compared with simulation results.

\section{RESULTS AND DISCUSSION}

One of the main drawbacks and challenges of the WPT method is low efficiency due to weak coupling. To overcome this disadvantage, many issues need to be considered such as coil design including shape, size, number of turns. The performance of the proposed PSCs (transmitter, single layer receiver and double layer receiver) were designed and optimized in the air and in human biological tissue using commercial field solver ANSOFT-HFSS 14.1 at operating frequency $13.56 \mathrm{MHz}$. For more validation, the proposed PSCs have been fabricated using a single layer substrate FR4 with thickness $\mathrm{t}_{\mathrm{s}}=1 \mathrm{~mm}$ and $\varepsilon_{\mathrm{r}}=4.4$. The simulation and fabrication results are plotted and analyzed to explain the coil's performance in air and whiten human tissue. All simulations tested at $6 \mathrm{~mm}$ of transmission distances and taken into considerations the resistance of the implantable load circuits is $300 \Omega$. Real and imaginary part of the modeling of the PSCs for the Transmitter coil (TX) and of the double layer PSC receiver (RX2) is blotted as shown in Fig. 10 and 11, respectively. Whereas Fig. 12 shows the 
J. Eng. Applied Sci., 14 (20): 7636-7646, 2019

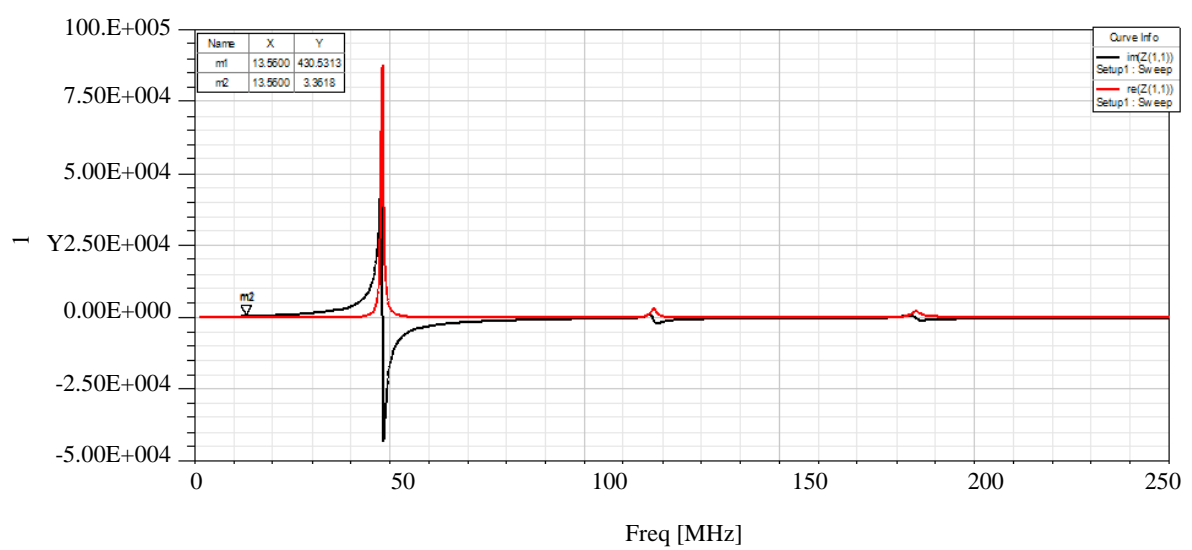

Fig. 10: Real and imaginary part represents the modeling of the PSCs for the transmitter coil (TX)

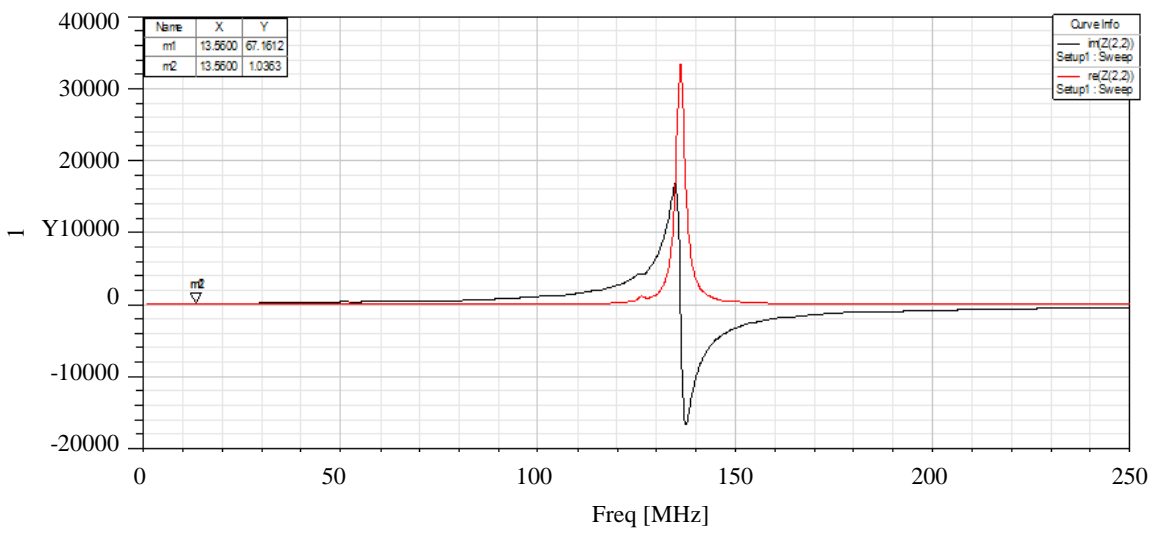

Fig. 11: Real and imaginary part represents the modeling of the double layer PSC receiver $\left(\mathrm{RX}_{2}\right)$

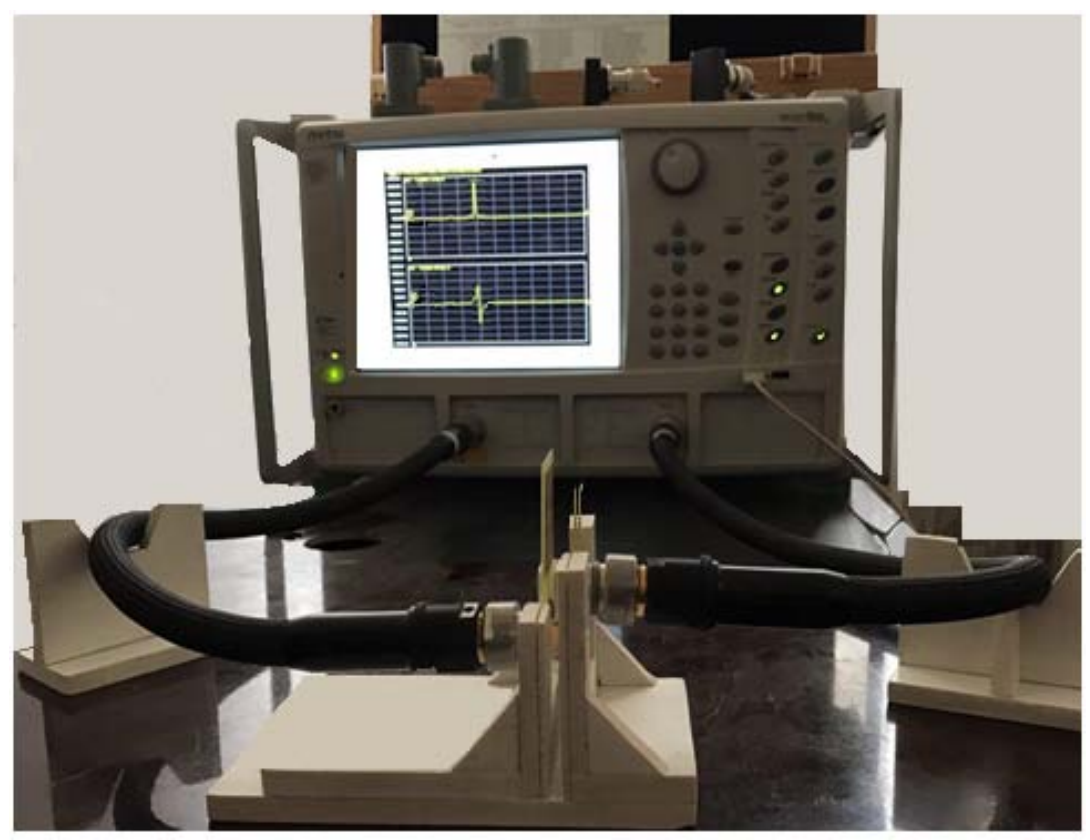

Fig. 12: Testing of the real and imaginary parts of the transmitter and double layer receiver 


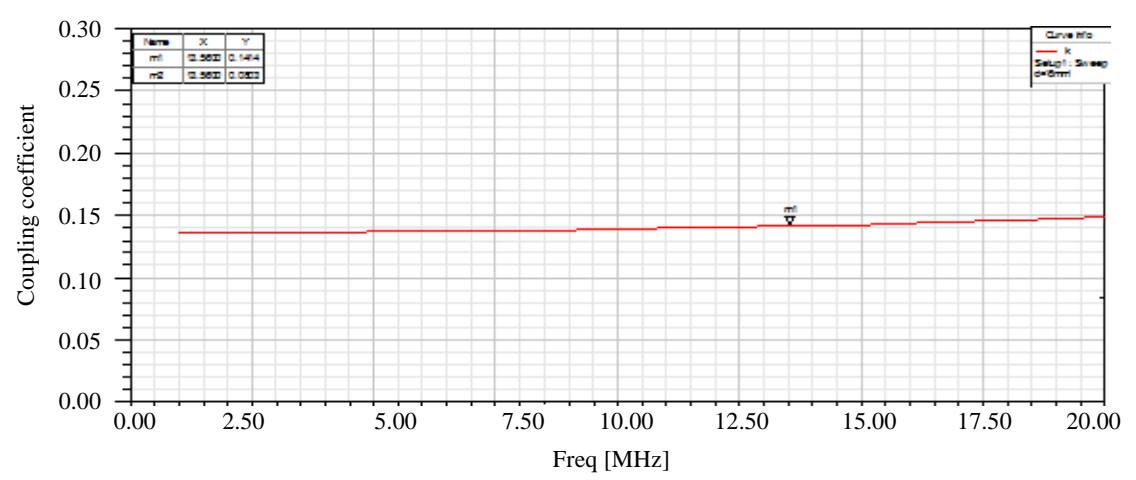

Fig. 13: Simulated of coupling coefficient $(\mathrm{k})$ for the single layer receiver at $6 \mathrm{~mm}$ of distance

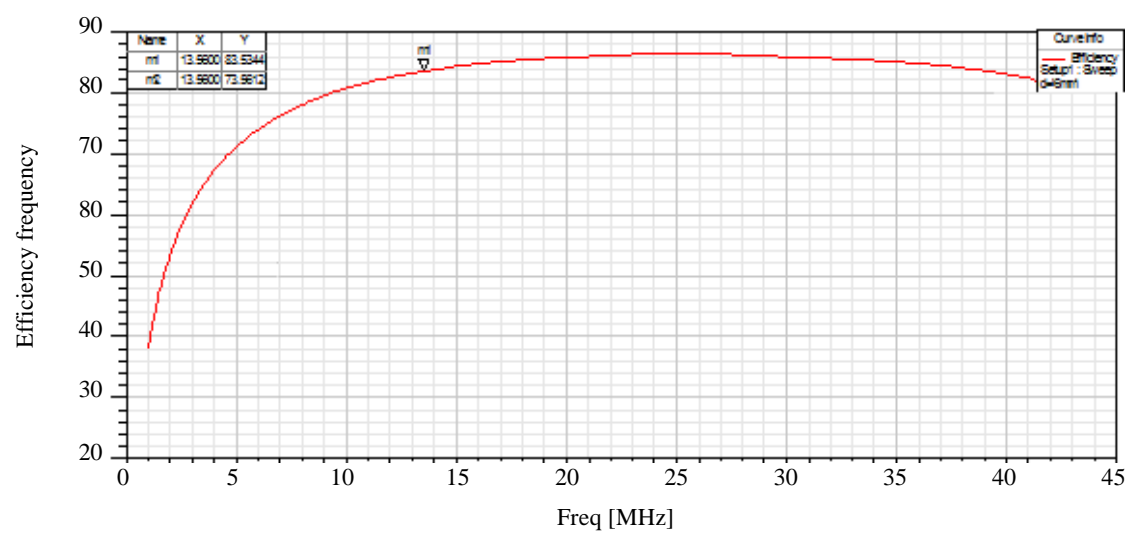

Fig. 14: Maximum power transmission efficiency at $6 \mathrm{~mm}$ distance at $13.56 \mathrm{MHz}$

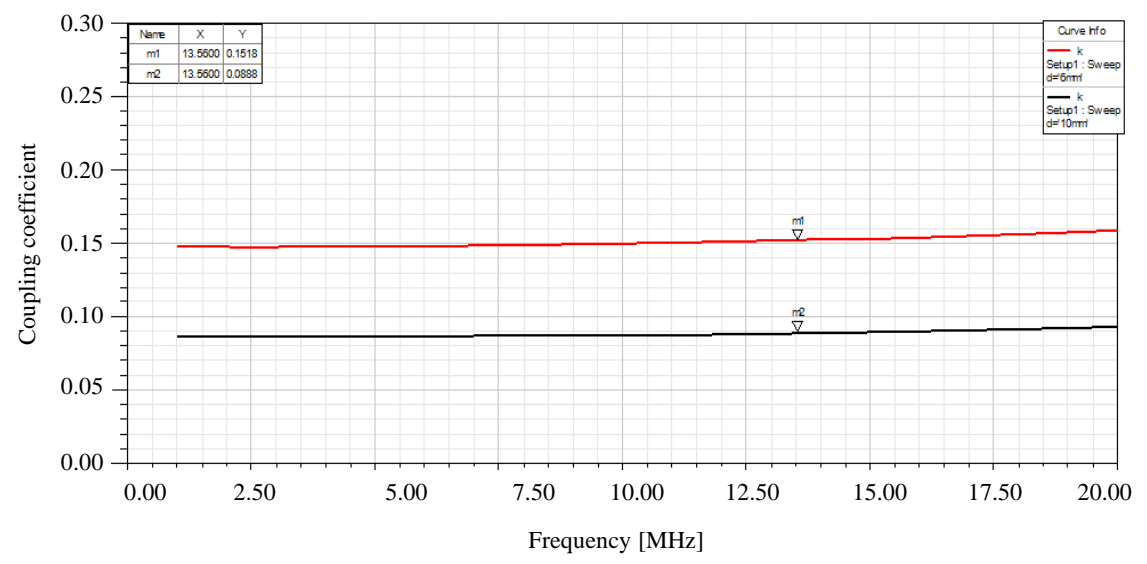

Fig. 15: The coupling coefficient (k) of the double layer receiver at 6 and $10 \mathrm{~mm}$ of distances

testing and measurement of the real and imaginary part of the modeling of the TX Coil and RX2 coil. To introduce the performance of the single layer receiver on air, the efficiency of the maximum wireless power transmission $\left(\mathrm{n}_{\max }\right)$ link and coupling coefficient $\mathrm{k}$ plotted in Fig. 13 and 14, respectively. Whereas Fig. 15 and 16 indicate the coupling coefficient and WPT of the double layer receiver on air at 10 and $6 \mathrm{~mm}$, respectively. It can be seen that the coupling coefficient and the power transmission efficiency is increased when the distance between coils decrease. To test the single layer and double layer receiver performance on tissue, both coils implanted 


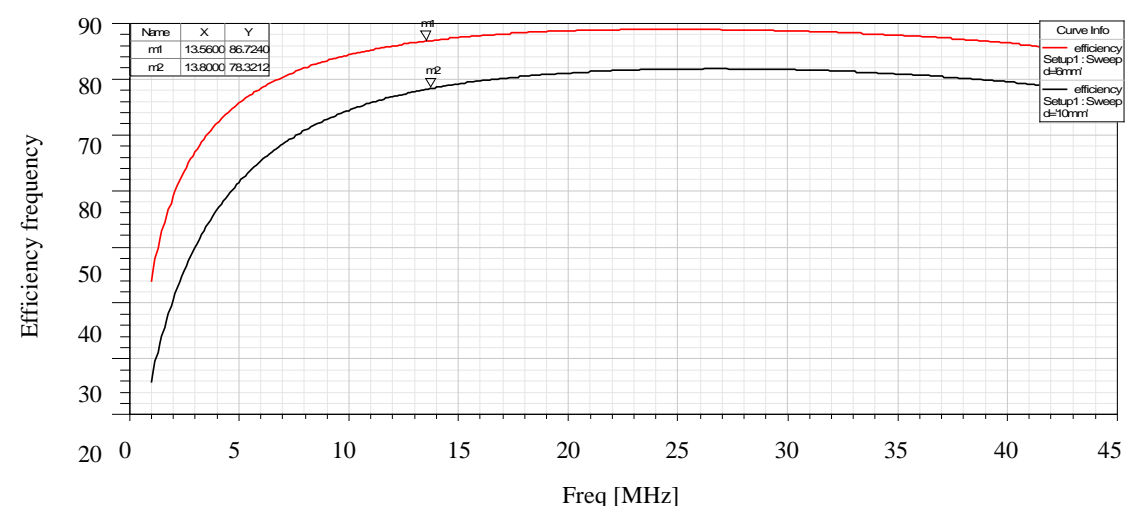

Fig. 16: Maximum power transmission efficiency at 6 and $10 \mathrm{~mm}$ of distance at different operating frequencies for the double layer receiver

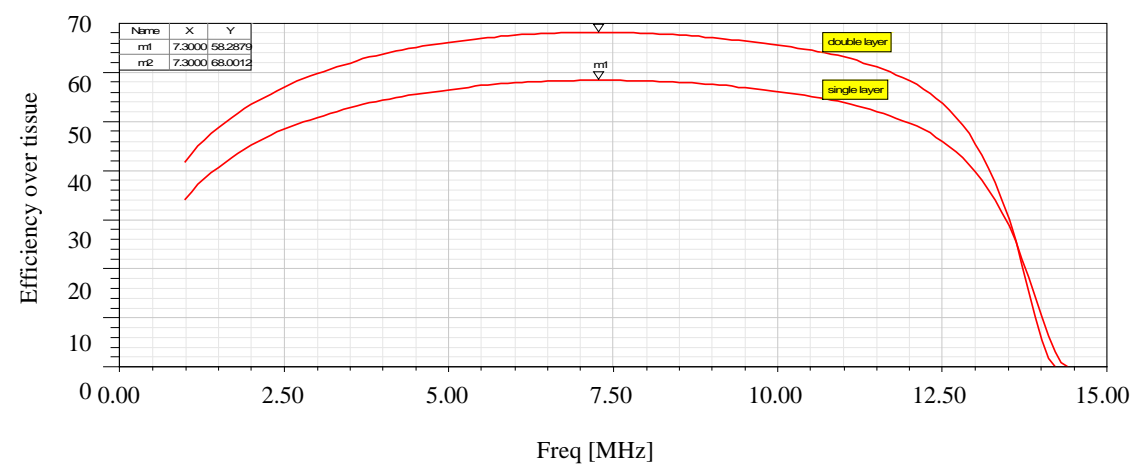

Fig. 17: HFSS electromagnetic results of power transfer efficiency in human tissue medium

Table 2: WPT link and efficiency results for the proposed coils

\begin{tabular}{lll}
\hline Parameters & Coil model & Values \\
\hline Coupling coefficient $(\mathrm{k})$ on air & Single layer & 0.141 \\
& Double lay er & 0.152 \\
Power transmission efficiency $(\Omega)$ on air & Single layer & $84.3 \%$ \\
& Double layer & $87 \%$ \\
Efficiency $(\Omega)$ with human tissue & Single layer & $58.29 \%$ \\
& Double layer & $68 \%$ \\
Efficiency $(\Omega)$ for experimental results on air & Double lay er & $59.5 \%$ \\
\hline
\end{tabular}

inside the human tissue at depth $6 \mathrm{~mm}$. Figure 17 manifests the power transmission efficiency results of the HFSS electromagnetic simulation with human tissue medium. The WPT Model performance in the tissues medium degenerates much worse in comparison with air medium. The peaks power efficiencies are 58.29 and $68 \%$ for single and double layer system respectively. It can be concluded that the double layer receiver have better efficiency over the single layer on air and within the human tissue. By using the SEMCAD Software it has been proven that implanted coil at $13.56 \mathrm{MHz}$ of operated frequency cannot damage the human tissue where the delivered power to the implanted coil is $78608 \mathrm{e}^{-0.26 \mathrm{w}}$ which is lower than the standard level for $1 \mathrm{~g}$ as shown in Fig. 18
(Anonymous, 1993). Figure 19 presents the measured of maximum power transmission efficiency where the measured WPT is $59.5 \%$.

All results of power efficiency are tested at low input impedance without taking into account the resistance and efficiency of the tuning circuit of the transmitter coil such as power amplifier. Table 2 provides the values of the coupling coefficient $(\mathrm{k})$ and WPT efficiency for the single layer and double layer on air and within human tissue, in addition, the efficiency for experimental results on air is presented. The maximum power efficiency is $84.3 \%$ and $87 \%$ at implanted load resistance $300 \Omega$ for both single and double layer systems, respectively. It is clearly can see that the power transmission efficiency of the double layer coil is higher than single layer receiver on air and within the tissue. The power transmission efficiency of the experimental results is $59.5 \%$. For more validations, the proposed work is compared to similar endeavors undertaken in this field as summarized in Table 3 . It can be observed that the power transfer efficiency achieved in this research is the highest with respect to the transmitter coil size and implant coil size. 


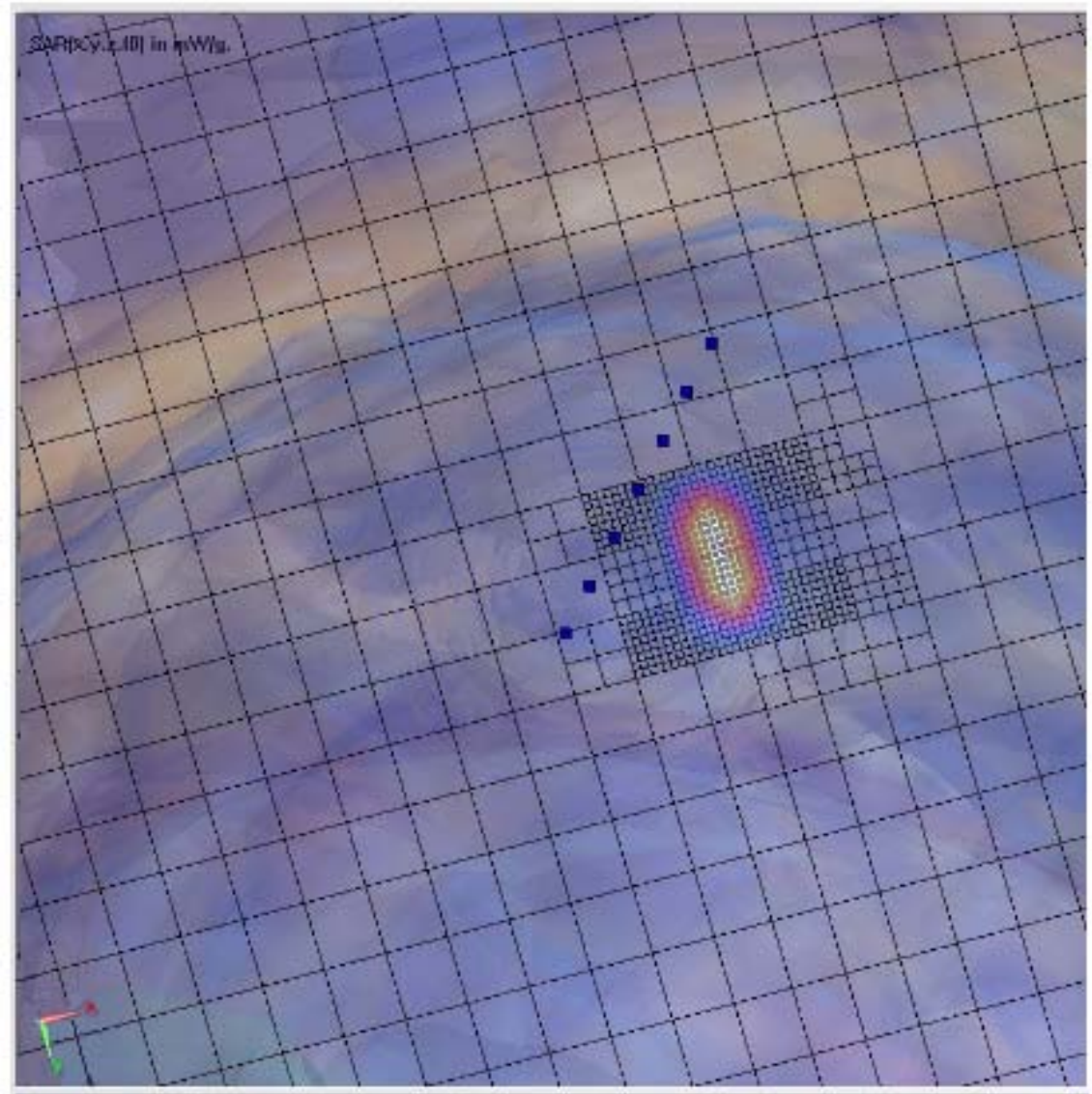

Delivered tied Power(to) at $0.01356 \mathrm{GHz}$

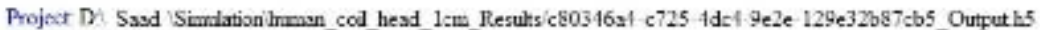
Fum. Simulaben 1

Seneor. Overal Field

Delinered power to field senser - [Condactivity Losses] - [Radasted Ponver] - 7.86508e $026 \mathrm{~W}$

Fig. 18: Delivered power to the implanted coil verified by SEMCAD Software

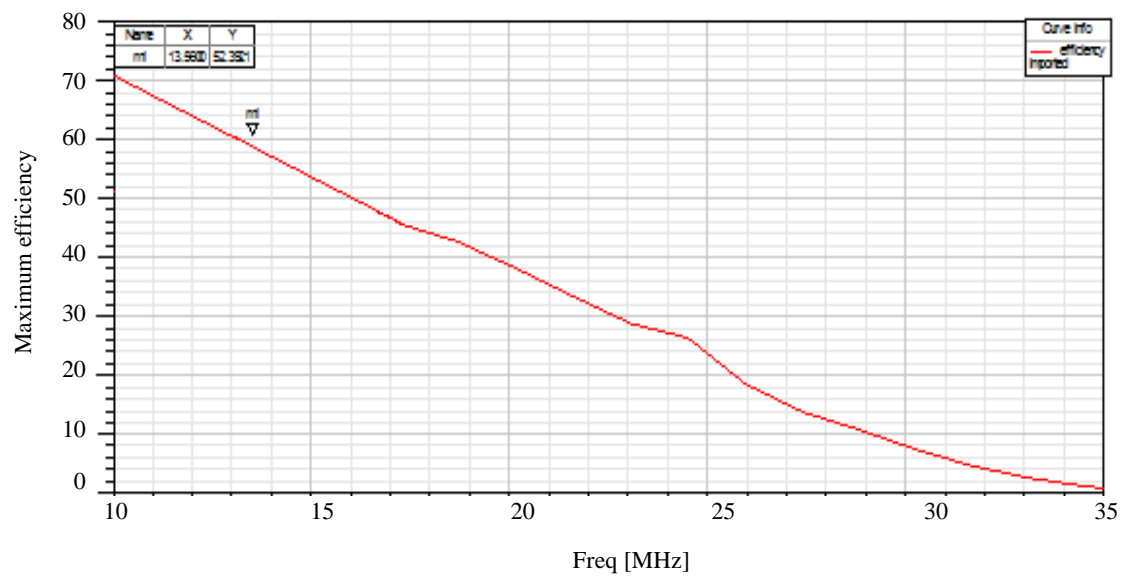

Fig. 19: Maximum power transmission efficiency at $6 \mathrm{~mm}$ distance for different operating frequencies 
Table 3: Comparison with previously published results

\begin{tabular}{|c|c|c|c|c|c|c|c|c|c|c|}
\hline \multirow[b]{2}{*}{ Researchers } & \multirow[b]{2}{*}{ Technique } & \multirow[b]{2}{*}{ PSCs shape } & \multirow{2}{*}{$\begin{array}{l}\text { Operation } \\
\text { frequency } \\
(\mathrm{MHz})\end{array}$} & \multicolumn{2}{|c|}{ TX size $(\mathrm{mm})$} & \multicolumn{2}{|c|}{$\mathrm{RX}$ size $(\mathrm{mm})$} & \multicolumn{3}{|c|}{ Efficiency (\%) } \\
\hline & & & & $\mathrm{d}_{0}$ & $\mathrm{~d}_{\mathrm{i}}$ & $\mathrm{d}_{0}$ & $\mathrm{~d}_{\mathrm{i}}$ & Simulation & Measurement & t Medium \\
\hline $\begin{array}{l}\text { Jow and } \\
\text { Ghovanloo } \\
(2008)\end{array}$ & 2 coil & Square & 13.56 & 79 & 11.2 & 10 & 2.96 & 52 & 51 & Air \\
\hline Jow and & 2 coil & Square & 13.56 & 38 & 14.9 & 10 & 5.8 & 74.86 & 72.22 & Air \\
\hline Ghovanloo & 2 coil & Square & 13.56 & 30 & 11.1 & 10 & 5.5 & 49.12 & 51.8 & Saline \\
\hline (2009) & 2 coil & Square & 13.56 & 24 & 9.4 & 10 & 7.2 & 27.70 & 30.84 & Muscle \\
\hline $\begin{array}{l}\text { Ahmadi and } \\
\text { Jullien (2009) }\end{array}$ & 2 coil & Rectangular & 13.56 & 44 & - & $4 \times 8$ & - & - & - & Air \\
\hline $\begin{array}{l}\text { Wu and } \\
\text { Fang (2011) }\end{array}$ & 2 coil & Square & $\begin{array}{l}13.56 \\
8\end{array}$ & & & & & $\begin{array}{l}71.1 \\
15.2\end{array}$ & - & $\begin{array}{l}\text { Air } \\
\text { Skin+Fat }\end{array}$ \\
\hline $\begin{array}{l}\text { Andia et al. } \\
\text { (2011) }\end{array}$ & 2 coil & Rectangular & 13.56 & $62 \times 25$ & - & $25 \times 10$ & - & - & - & Air \\
\hline $\begin{array}{l}\text { Abbas et al. } \\
(2013)\end{array}$ & 2 coil & Circular & 13.56 & 56 & 10 & 11.6 & 5 & 78 & - & Air \\
\hline $\begin{array}{l}\text { Stocklin et al. } \\
\text { (2015) }\end{array}$ & 2 coil & $\begin{array}{l}\text { Circular } \\
\text { Circular with ferrite core }\end{array}$ & 13.56 & 30 & - & 10 & 4.3 & $\begin{array}{l}55 \\
60\end{array}$ & $\begin{array}{l}59 \\
66\end{array}$ & Air \\
\hline \multirow[t]{2}{*}{$\begin{array}{l}\text { Yang et al. } \\
\text { (2017) }\end{array}$} & 4 coil & Square & 13.56 & \multicolumn{2}{|c|}{ Source coil (helical) } & $\begin{array}{l}\text { Load coil } \\
5\end{array}$ & - & - & Air & \\
\hline & & & & $\begin{array}{l}\text { Primary } \\
24\end{array}$ & $\begin{array}{r}\text { coil } \\
8.5\end{array}$ & $\begin{array}{l}\text { Secondary } \\
5\end{array}$ & il 2.3 & - & - & Muscle \\
\hline $\begin{array}{l}\text { This } \\
\text { researcher }\end{array}$ & $\begin{array}{l}2 \text { coil with } \\
\text { single layer }\end{array}$ & Square & 13.56 & 30 & 7.6 & 10 & 5.4 & $\begin{array}{l}84.3 \\
58.29 \text { at } \\
6 \mathrm{~mm}\end{array}$ & - & $\begin{array}{l}\text { Air } \\
\text { Skin+Fat } \\
+ \text { Muscles }\end{array}$ \\
\hline- & $\begin{array}{l}2 \text { coil } \\
\text { (double } \\
\text { layer receiver) }\end{array}$ & Square & 13.56 & 30 & 7.6 & 10 & 7.6 & $\begin{array}{l}87 \\
68 \text { at } 6 \mathrm{~mm}\end{array}$ & - & $\begin{array}{l}\text { Air } \\
\text { Skin+Fat+ } \\
\text { Muscles }\end{array}$ \\
\hline
\end{tabular}

\section{CONCLUSION}

In this study, a small size of square transmitter coil and mall size of efficient square double layers without tuning capacitor is designed and fabricated to be used for medical implants. The proposed design tested on air and within the human tissue at deep of $6 \mathrm{~mm}$, in addition, a single layer receiver is also, designed to be compared with the double layer design. The wireless power transmission for the single layer on air is $84.3 \%$ and within the human tissue is $58.29 \%$ whereas for the double layer on air is $87 \%$ and within the human tissue is $68 \%$. Hence, the double layer have better efficiency than single layer by $2.7 \%$ on air and $9.71 \%$ within the phantom tissue. In addition, the proposed double layer coil cannot damage the human tissue and it is safe to be used for deep brain stimulator.

\section{REFERENCES}

Abbas, S.M., M.A. Hannan, S.A. Samad and A. Hussain, 2013. Design of spiral circular coils in wet and dry tissue for Bio-implanted micro-system applications. Prog. Electromagnet. Res. M, 32: 181-200.

Ahmadi, M.M. and G.A. Jullien, 2009. A wireless-implantable microsystem for continuous blood glucose monitoring. IEEE. Trans. Biomed. Circuits Syst., 3: 169-180.
Andia, L., R.F. Xue, K.W. Cheng and M. Je, 2011. Closed loop wireless power transmission for implantable medical devices. Proceedings of the 2011 International Symposium on Integrated Circuits, December 12-14, 2011, IEEE, Singapore, ISBN: 978-1-61 284-863-1, pp: 404-407.

Anonymous, 1993. Understanding the fec regulations for low-power, non-licensed transmitters. Federal Communications Commission Office of Engineering and Technology, Washington, DC., USA., https://docplayer.net/95050-Understanding-the-fccregulations-for-low-power-non-licensed-transmitter s.html

Ashoori, E., F. Asgarian, A.M. Sodagar and E. Yoon, 2011. Design of double layer printed spiral coils for wirelessly-powered biomedical implants. Proceedings of the 2011 Annual International Conference of the IEEE Engineering in Medicine and Biology Society, August 30-September 3, 2011, IEEE, Boston, Massachusetts, USA., ISBN :978-1-4244-4121-1, pp: 2882-2885.

Bahl, I.J., 2003. Lumped Elements for RF and Microwave Circuits. Artech House, Norwood, Massachusetts, USA., Pages: 464.

Hannan, M.A., S. Mutashar, S.A. Samad and A. Hussain, 2014. Energy harvesting for the implantable biomedical devices: Issues and challenges. BioMed. Eng. OnLine, Vol. 13. 
Jow, U.M. and M. Ghovanloo, 2007. Design and optimization of printed spiral coils for efficient transcutaneous inductive power transmission. IEEE. Trans. Biomed. Circuits Syst., 1: 193-202.

Jow, U.M. and M. Ghovanloo, 2008. Optimization of a multiband wireless link for neuroprosthetic implantable devices. Proceedings of the 2008 IEEE International Conference on Biomedical Circuits and Systems, November 20-22, 2008, IEEE, Baltimore, Maryland, USA., ISBN: 978-1-4244-2878-6, pp: $97-100$.

Jow, U.M. and M. Ghovanloo, 2009. Modeling and optimization of printed spiral coils in air, saline and muscle tissue environments. IEEE. Trans. Biomed. Circuits Syst., 3: 339-347.

Medhurst, R.G., 1947. HF resistance and self-capacitance of single-layer solenoids. Wirel. Eng., 24: 35-43.

Mutashar, S. and M.A. Hannan, 2013. [Efficient low-power recovery circuits for bio-implanted micro-sensors (In Polish)]. Electrotechnical Rev. ERJ., 89: $15-18$.
Raju, S., R. Wu, M. Chan and C.P. Yue, 2014. Modeling of mutual coupling between planar inductors in wireless power applications. IEEE. Trans. Power Electron., 29: 481-490.

Stocklin, S., T. Volk, A. Yousaf, J. Albesa and L. Reindl, 2015. Efficient inductive powering of brain implanted sensors. Proceedings of the 2015 International Symposium on IEEE Sensors Applications (SAS), April 13-15, 2015, IEEE, Zadar, Croatia, pp: 1-6.

$\mathrm{Wu}, \mathrm{W}$. and Q. Fang, 2011. Design and simulation of printed spiral coil used in wireless power transmission systems for implant medical devices. Proceedings of the 2011 IEEE Annual International Conference on Engineering in Medicine and Biology Society, August 30-September 3, 2011, IEEE, Boston, Massachusetts, USA., ISBN:978-1-4244-4121-1, pp: 4018-4021.

Yang, C.L., C.K. Chang, S.Y. Lee, S.J. Chang and L.Y. Chiou, 2017. Efficient four-coil wireless power transfer for deep brain stimulation. IEEE Trans. Microwave Theory Tech., 65: 2496-2507. 